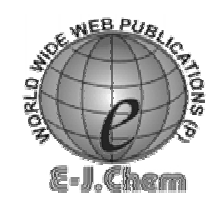

http://www.e-journals.net
ISSN: 0973-4945; CODEN ECJHAO

E-Journal of Chemistry

Vol. 5, No. 2, pp. 271-274, April 2008

\title{
Selective Transport of Silver(I) Ion Through Polymer Membranes Containing Thioether Donor Macrocycles as Carriers
}

\author{
A. NEZHADALI* and M. AKBARPOUR \\ *Deparment of Chemistry, Payan-Noor University of Mashhad, Mashhad, Iran \\ Deparment of Chemistry, Payan-Noor University of Bujnord, Bujnord, Iran \\ aziz_nezhadali@yahoo.com
}

Received 15 July 2007; Accepted 10 September 2007

\begin{abstract}
The Preparation of polymer membrane and it's selectivity to silver(I) ion from an aqueous solution containing seven metal cations, $\mathrm{Co}(\mathrm{II}), \mathrm{Ni}(\mathrm{II})$, $\mathrm{Cu}(\mathrm{II}), \mathrm{Zn}(\mathrm{II}), \mathrm{Ag}(\mathrm{I}), \mathrm{Cd}(\mathrm{II})$ and $\mathrm{Pb}(\mathrm{II})$, was studied. The source phase contained equimolar concentrations of the above mentioned cations with the source and receiving phases being buffered at $\mathrm{pH} 5.0$ and 3.0 respectively. The effect of variation in the number of the macrocyclic sulfur atom donor set anssd the size of ring 9 and 16 member macrocycles on transport efficiency is presented. Silver(I) ion transport occurred $\left(\right.$ at $25{ }^{\circ} \mathrm{C}$ ) from the aqueous source phase across the polymer membrane (derived from cellulos triacetate) containing ligands 9membered, $\mathrm{S}_{3}$-donor and16-membered $\mathrm{S}_{4}$-donor macrocycles as the ionophors in separate experiments into the aqueous receiving phase. Clear transport selectivity for silver(I) ion was observed using both thioether donor macrocycles. The efficiency of transport rate for silver(I) ion with using 9-membered $\mathrm{S}_{3}$-donor macrocycle as carrier was better than 16-membered $\mathrm{S}_{4}$-donor .
\end{abstract}

Keywords: Membrane; Silver(I); Cellulose triacetate; Transport of silver ion

\section{Introduction}

The selectivity transport of silver(I) ion from the solutions containing heavy metal cations through bulk liquid membranes using wide rang of macrocyclic and acyclic ionophores containing sulfur, nitrogen and oxygen donor atoms have been reported ${ }^{1-7}$. The differences between single- species and competitive solvent extraction using crown ethers for some metal cations have also been studied ${ }^{8}$. The transport of cations through supported liquid membrane mediated by neutral carriers can be regarded as a sequential process including phase transfer of salt, Complexation/ decomplexation, and diffusion steps. The rate of.transport depend to the mentioned process ${ }^{9}$. Polymer inclusion membranes are gel- like membranes incorporating into their matrix plasticizer(s) and ionophore. In previous investigation it has been employed 
cellulose triacetate based membranes in transport experiments involving selective transport of $\mathrm{Cu}$ (II) ion from a solution containing seven metal cations ${ }^{10}$. Polymer inclusion membranes show a member of advantages over more traditional member systems. The incorporation of the ionohpore into a polymer inclusion membrane tend to 'secure' it and hence inhibit leaching into the aqueous phases without the need for increased lipophilicity of the ligand or the addition of a lipophilic acid as often employed in the bulk liquid membrane systems. The more durable polymer inclusion membranes have also been shown to exhibit higher rates of transport for Group 1 metal ions than thin supported liquid membranes under defined conditions ${ }^{11}$. It has also been demonstrated that transport rates are dependent on the concentration of an ionophore and the plasticizer in the polymer membrane ${ }^{11-16}$.

In the present report, the results of competitive metal polymer inclusion transport involving $\mathrm{Co}(\mathrm{II}), \mathrm{Ni}(\mathrm{II}), \mathrm{Zn}$ (II), $\mathrm{Cu}$ (II), $\mathrm{Ag}$ (I), $\mathrm{Cd}$ (II) and $\mathrm{Pb}$ (II) using carriers 1 and 2 (Diagram I) are presented.

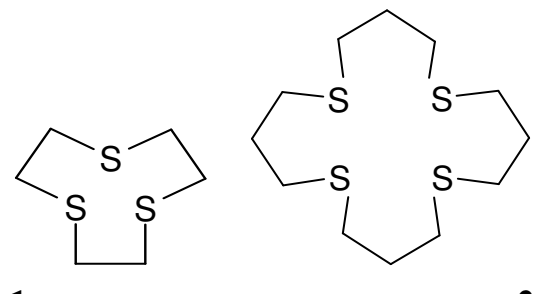

1

2

\section{Experimental}

Diagram I.

\section{Reagents}

All reagents were of analytical grade and were used without further purification. The ligands also were obtained commercially.

\section{Transport experiments}

The polymer membranes using ligands $\mathbf{1}$ and $\mathbf{2}$ were made based on that described previously ${ }^{10}$. The source phase was buffered at $\mathrm{pH}$ 5.0 $\left(\mathrm{CH}_{3} \mathrm{COOH} / \mathrm{CH}_{3} \mathrm{COONa}\right)$. The metal ions present at a concentration of $0.01 \mathrm{M}$ were cobalt(II), nickel(II), copper(II), zinc(II), silver(I), cadmium(II) and lead(II), all as their nitrate salts. The receiving phase was buffered at $\mathrm{pH} 3.0(\mathrm{HCOOH} / \mathrm{HCOONa})$. The transport cell was based on that described previously ${ }^{10}$. The volume of each of the source and receiving phases was $130 \mathrm{~mL}$. The transport runs were carried out for a period of $24 \mathrm{~h}$ and the stirring speed was $50 \mathrm{rpm}$ at $25^{\circ} \mathrm{C}$. The metal ion concentrations in the both receiving and source phases after each transport was determined using PU9100X Philips atomic absorption spectrometer. The transport results are quoted as average values obtained from triplicate runs.

\section{Results and Discussion}

The 9 and 16 membered ligands $\mathbf{1}$ and $\mathbf{2}$ were used as selective extractant for $\operatorname{Ag}(\mathrm{I})$ ion from a solution containing seven metal cations. The results of competitive transport experiments are shows in Table 1. As it is shown in Table 1 both ligands completely preference for the transport of silver(I) ion across the polymer membrane. This is similar to the behaviour observed in the corresponding competitive similar membrane transport studies. The Selectively bulk liquid membrane transport of silver(I) ion with macrocycles $\mathbf{1}$ and $\mathbf{2}$ have been reported previously ${ }^{5}$. As it is shown in Table 1, ligand $\mathbf{1}$ transport silver(I) ion across the polymer membrane more than 2 . 
Table 1. Transport fluxes for silver(I) in seven-metal competitive transport across a polymer membrane employing 1 and 2 as ionophores $\left(25^{\circ} \mathrm{C}\right)$.

\begin{tabular}{ccc}
\hline \multirow{2}{*}{ Cation } & \multicolumn{2}{c}{ Flux $(\mathrm{mol} / \mathrm{h})$} \\
\cline { 2 - 3 } & 1 & 2 \\
\hline $\mathrm{Co}(\mathrm{II})$ & - & - \\
$\mathrm{Ni}(\mathrm{II})$ & - & - \\
$\mathrm{Cu}(\mathrm{II})$ & - & - \\
$\mathrm{Zn}(\mathrm{II})$ & - & - \\
$\mathrm{Cd}(\mathrm{II})$ & - & - \\
$\mathrm{Ag}(\mathrm{I})$ & $8.42 \times 10^{-7}$ & $6.96 \times 10^{-7}$ \\
$\mathrm{~Pb}(\mathrm{II})$ & - & - \\
\hline
\end{tabular}

The previous studies ${ }^{5}$ show that the nine-membered, $\mathrm{S}_{3}$-donor ligand (1) is a little better ionophor for transport of silver (I) ion across the chloroform membrane with flux rate of $105 \times 10^{-7} \mathrm{~mol}(24 \mathrm{~h})^{-1}$ (ligand 2 flux rate is $\left.103 \times 10^{-7} \mathrm{~mol}(24 \mathrm{~h})^{-1}\right)$. The comparison of the flux rate of the competitive polymer membrane transports with ligands $\mathbf{1}$ and $\mathbf{2}$ and their bulk liquid transport for silver(I) ion show a similarity in the order of flux rates. It seems the formation of $\left[\mathrm{Ag} . \mathbf{1}_{2}\right]^{+}$complex ${ }^{5}$ with ligand $\mathbf{1}$, is the main reason of more transport of silver(I) ion with this ligand respect to 2 with a 1:1 complex between it and $\operatorname{Ag}(\mathrm{I})$ ion. Figures 1 and 2 show the curves of the results of the competitive metal ion polymer inclusion

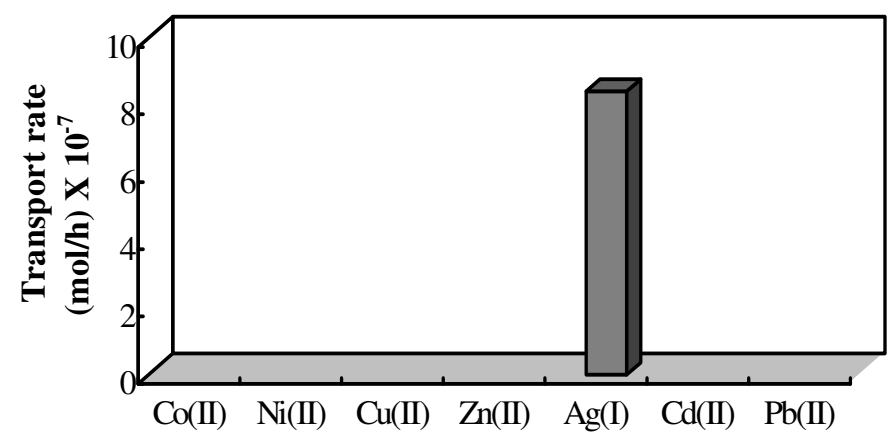

Metal ion

Figure 1. The rate of transport $(\mathrm{mol} / \mathrm{h})$ for a competitive metal-ion transport (source/membrane/receiving) study, using 1 incorporated into a polymer inclusion membrane. Aqueous source phase: $130 \mathrm{~mL}$, contains seven metal ions, each with initial concentration $0.01 \mathrm{M}$ prepared in a buffer solution $\left(\mathrm{CH}_{3} \mathrm{COOH} / \mathrm{CH}_{3} \mathrm{COONa}\right) \mathrm{pH}$ 5.0. Membrane polymer phase contain ligand $(0.01 \mathrm{M})$. Aqueous receiving phase: a buffer solution of $\mathrm{HCOOH} / \mathrm{HCOONa}, \mathrm{pH} 3.0(130 \mathrm{~mL})$; both liquid phases stirred for 24 hours at $25^{\circ} \mathrm{C}$. The transport rate for $\mathrm{Ag}(\mathrm{I})$ is the average taken from a triplicate runs.transports. The observed $\mathrm{Ag}(\mathrm{I})$ transport rate are $\mathrm{J}=8.42 \times 10^{-7} \mathrm{~mol} / \mathrm{h}$ and $6.96 \times 10^{-7} \mathrm{~mol} / \mathrm{h}$ for ligands 1 and 2 respectively. The rate of transport for silver(1) ion using 1 is about 1.2 times of 2 . 


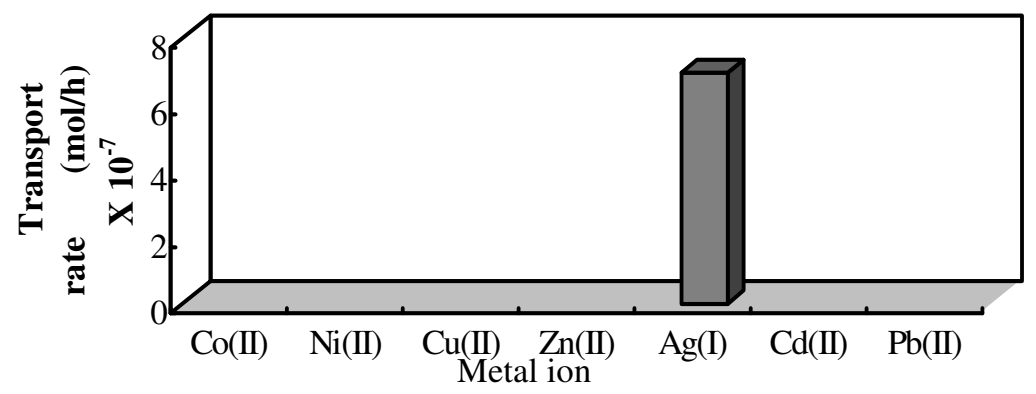

Figure 2. The rate of transport $(\mathrm{mol} / \mathrm{h})$ for a competitive metal-ion transport (source/membrane/receiving) study, using $\mathbf{2}$ incorporated into a polymer inclusion membrane. Aqueous source phase: $130 \mathrm{~mL}$, contains seven metal ions, each with initial concentration $0.01 \mathrm{M}$ prepared in a buffer solution $\left(\mathrm{CH}_{3} \mathrm{COOH} / \mathrm{CH}_{3} \mathrm{COONa}\right) \mathrm{pH} 5.0$. Membrane polymer phase contain ligand $(0.01 \mathrm{M})$. Aqueous receiving phase: a buffer solution of $\mathrm{HCOOH} / \mathrm{HCOONa}, \mathrm{pH} 3.0(130 \mathrm{~mL})$; both liquid phases stirred for 24 hours at $25^{\circ} \mathrm{C}$. The transport rate for $\operatorname{Ag}(\mathrm{I})$ is the average taken from a triplicate runs.

\section{Conclusion}

All these results confirms that the both ligands are an efficient reagents showing high specificity for $\mathrm{Ag}(\mathrm{I})$ in both bulk liquid membrane and polymer inclusion transport experiments under the conditions employed. Also the more efficiency of $\mathbf{1}$ for the transport $\mathrm{Ag}(\mathrm{I})$ ion is observed.

\section{Acknowledgments}

The authors thank Research Council of Payam-Noor University for financial support.

\section{References}

1. Black D, Blacke A J, Finn RL, Lindoy L F, Nezhadali A, Rounaghi Gh, Tasker P A and Schroder M, J. Chem. Soc. Chem. Commun., 2002, 4, 340.

2. Kim J, Leong A J, Lindoy L F, Kim J, Nachbaur J, Nezhadali A and Rounaghi Gh, Wei G, J. Chem.Soc., Dalton Trans., 2000, 19 , 3453.

3. Lee S S, Yoon I, Park K M, Jung J H, Lindoy L F, Nezhadali A and Rounaghi Gh, J. Chem. Soc., Dalton Trans. 2002, 10, 2180.

4. Chia P J K, Leong A J, Lindoy L F and Walker G W, Aust. J. Chem. 1995, 48, 879.

5. Melnikova M F, Lindoy L F, Liou S Y, Mcmurtrie J C, Green N P, Nezhadali A, Rounaghi Gh and Setzer W N, Aust. J.Chem. 2004, 57, 161.

6. Parthasarathy N, Pelletier M and Buffle J, Analytica Chimica Acta 1997, 350, 183.

7. Parthasarathy N and Buffle J, Analytica Chimica Acta, 1991, 245, 9.

8. Talanova G G, Elkarim N S A, Hanes R E, Hwang H S, Rogers R D and Bartsch R A, Anal. Chem. 1999, 71, 672.

9. Rechewein-Buitenhuis E G, Visser H C, Jong F and Reinhoud D N J. Am. Chem. Soc. 1995, 117, 3913.

10. Nezhadali A, Incl. Phen. Mol. Recogn., 2006, 54,307.

11. Lamb J D, Schow A J and Peterson T R J. Membr. Sci. 1996, 111, 291.

12. Sugiura M, Sep. Sci. Technol. 1990, 25, 1189.

13. Izatt R M, Lam J D and Bruending R L Sep. Sci. Technol. 1988, 23, 1945.

14. Ruppert M, Draxler J and Marr R, Sep.Sci. Techanl. 1988, 23, 1654.

15. Sugiura M and Kikkawa, Sep.Sci.Techanl. 1987, 22, 2263.

16. Sugiura M, Sep.Sci.Techanl.1992, 27, 269. 


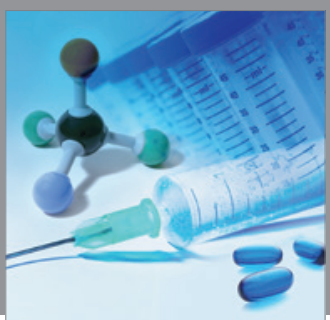

International Journal of

Medicinal Chemistry

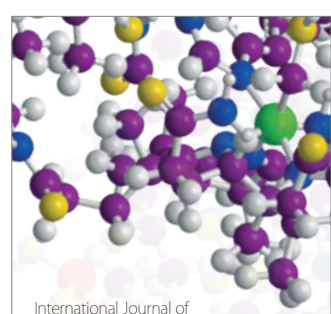

Carbohydrate Chemistry

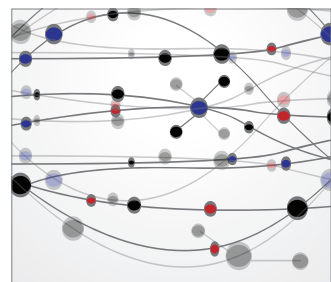

The Scientific World Journal
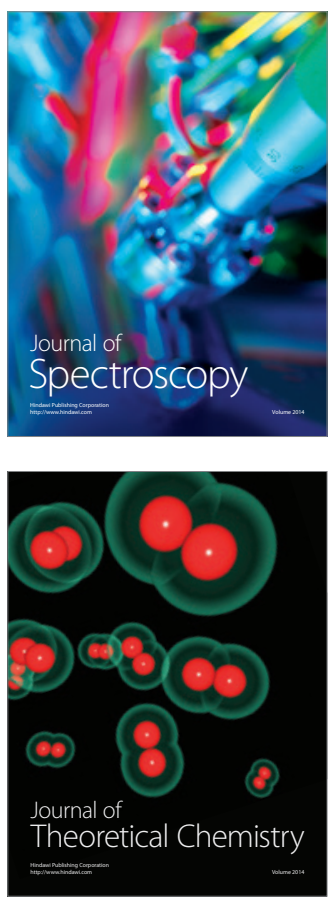
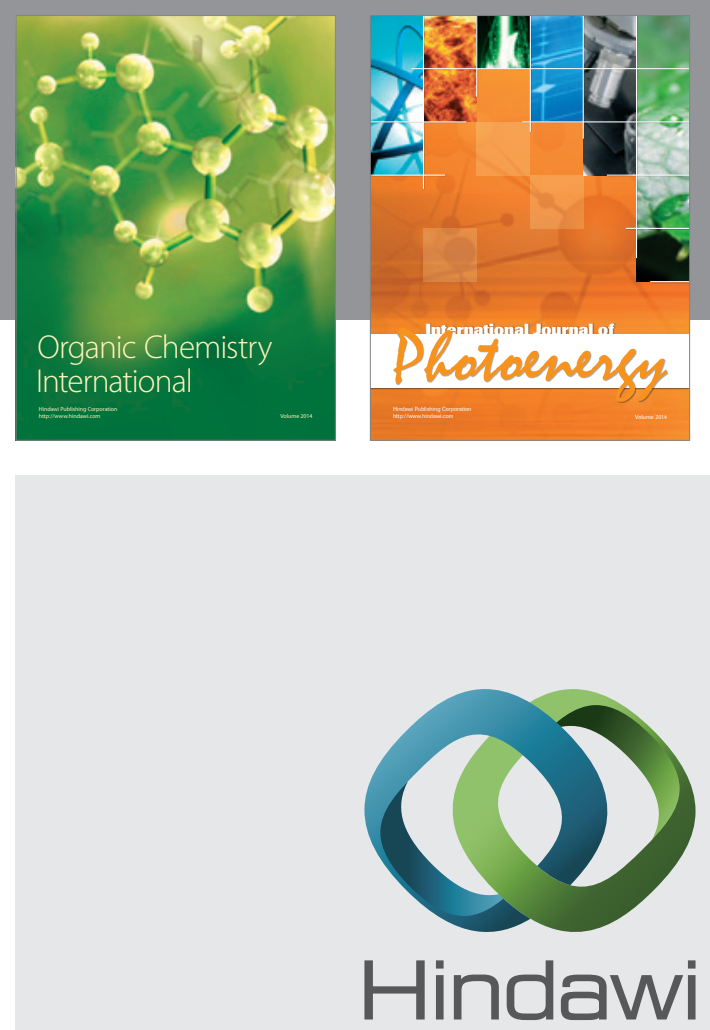

Submit your manuscripts at

http://www.hindawi.com
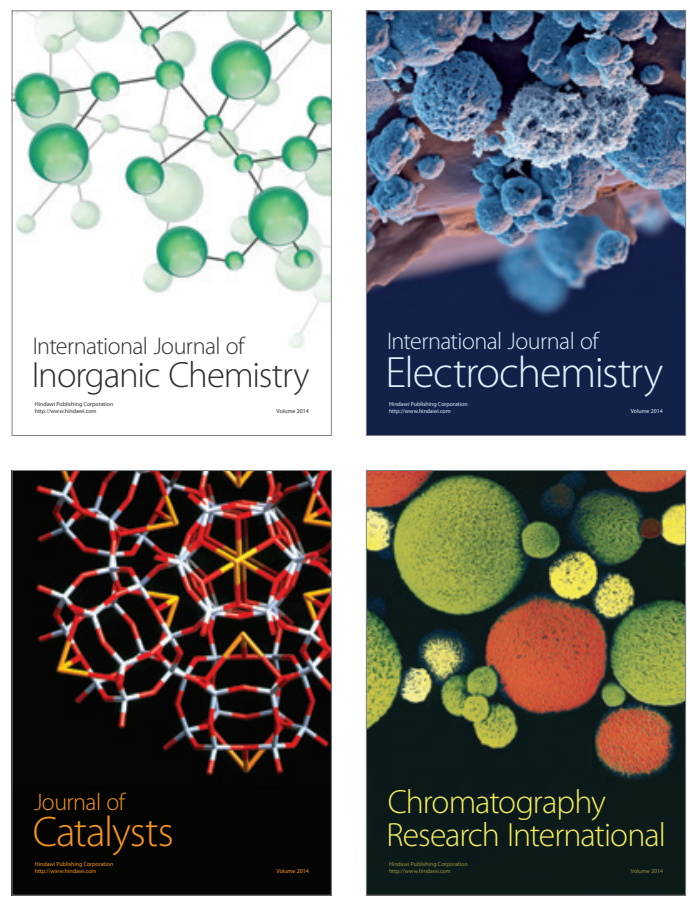
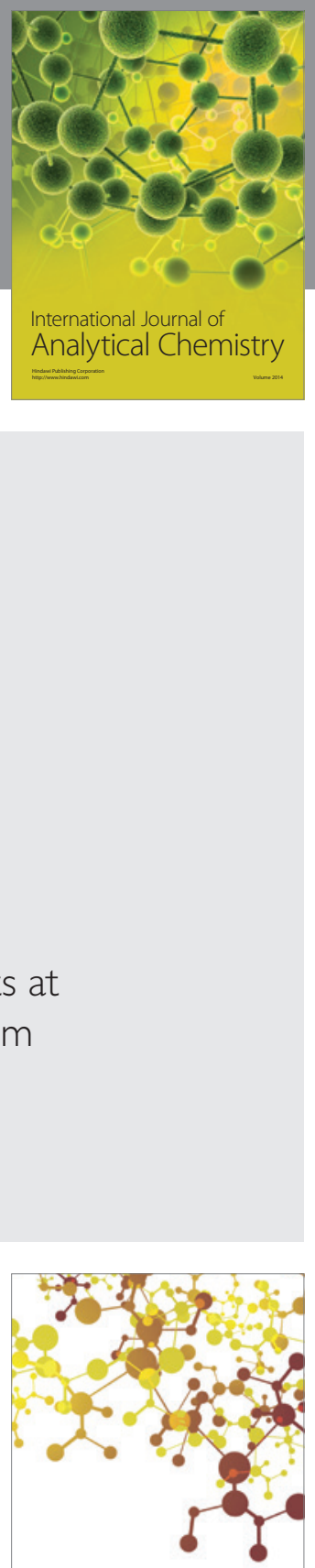

Journal of

Applied Chemistry
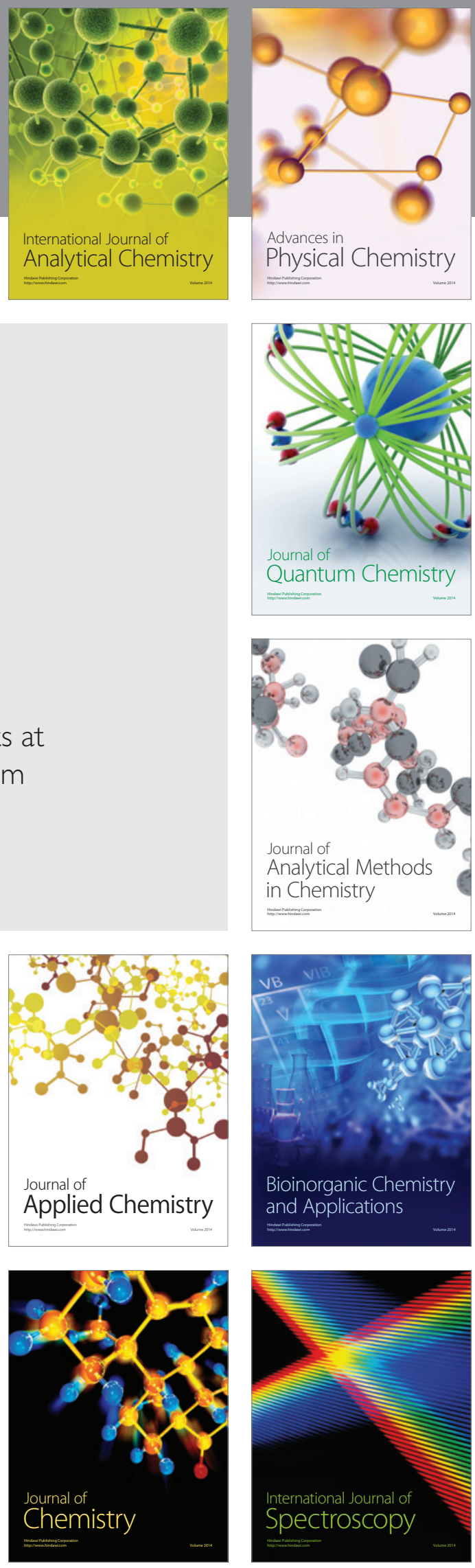